Eixo Temático: Desenvolvimento de Estratégias Didáticas

\title{
ET-07-015 \\ O USO DE ATIVIDADES PRÁTICAS COMO AGENTE FACILITADOR PARA O ENSINO DE CIÊNCIAS: UM RELATO DE EXPERIÊNCIA DOCENTE
}

Bruna Rafaelle Bernardo da Silva, Eduardo Araújo da Silva, Jéssica Barboza da Silva, Marianne Firmino de Oliveira

Universidade Federal de Pernambuco - UFPE.

http://dx.doi.org/10.21472/congrebio2016.et-07-015

\section{RESUMO}

O presente trabalho tem por objetivo relatar a vivência de um estágio obrigatório supervisionado que teve o intuito de analisar a desenvoltura de alunos da educação básica de uma escola estadual do estado de Pernambuco diante de atividades práticas e experimentais. Com o trabalho realizado foi possível perceber uma intensa interação entre alunos, professores e toda a equipe gestora assim como um melhor desempenho de toda a turma submetida à atividade. Tornou-se evidente aos estagiários a importância das atividades práticas para o ensino de ciências contribuindo assim na vida profissional e pessoal dos envolvidos.

Palavras-chave: Estágio; Ciências; Práticas.

\section{INTRODUÇÃO}

O estudo por meio da experimentação associada ao conteúdo teórico é fundamental para o processo de ensino-aprendizagem. Nesse sentido é possível perceber que diversos profissionais utilizam com maior freqüência o método tradicional esquecendo por muitas vezes as atividades práticas, sendo justificada pela falta de infra-estrutura, quantidade excessiva de alunos por sala e a questão de carga horária muitas vezes reduzida impossibilitando a realização das atividades (PEREIRA, 2010).

Nesse contexto é importante destacar o fato de as atividades experimentais trazerem um maior envolvimento dos alunos entre si e com os professores gerando conseqüências positivas para o desempenho escolar. O conhecimento é produzido muitas vezes a partir da inserção do aluno no meio em que ele vive, para que dessa forma possa permitir a atribuição de significados resultando na assimilação dos conteúdos. As atividades experimentais incluem muitas vezes demonstrações feitas pelo professor que justificam as informações teóricas, já dadas, onde a interpretação leva muitas vezes a formação de conceitos (MALDANER, 1999).

Dessa forma, o presente trabalho visa analisar o desenvolvimento de duas turmas de uma escola estadual, situada no estado de Pernambuco, na zona norte do Recife, através da inserção de atividades experimentais. A atividade foi realizada durante o estágio supervisionado obrigatório que tem por finalidade preparar o estagiário para a realização de atividades na escola, com os professores nas salas de aula, bem como para a análise, avaliações e crítica (PIMENTA 2004, p. 120).

Os cursos de formação profissional oferecem conhecimentos científicos e possibilitam aos discentes a execução de atividades práticas sob forma de estágio supervisionado. Nesse sentido é importante destacar que o estágio é de extrema importância no processo de formação profissional, pois possibilita a relação teoria-prática, conhecimentos do campo de trabalho, conhecimentos pedagógicos, organização escolares e diversos outros fatores. 


\section{OBJETIVOS}

O trabalho teve como objetivo fazer uma analogia do desenvolvimento dos alunos com atividades teóricas e quando são submetidos a atividades teóricas e práticas ou experimentais complementando-se entre si, auxiliando no processo de formação profissional dos estagiários envolvidos no presente trabalho.

\section{MATERIAIS E MÉTODOS}

O projeto de estágio foi ministrado nas turmas do nono ano do turno da tarde de uma escola estadual do Recife, situada no bairro de Nova descoberta. Inicialmente foram realizadas observações com o intuito de traçar o perfil das turmas e analisar o ambiente escolar, num período de duas semanas. Posteriormente o projeto elaborado foi ministrado.

A instituição de ensino estava iniciando projetos para feira de conhecimento que tinha como tema central, qualidade de vida. Nesse sentido iniciamos com aulas teóricas retratando fatos relacionados ao tema central. Foram realizadas aulas teóricas abordando os segmentos do tema central para as turmas selecionadas para intervenção. Posteriormente as elas foram divididas em grupos, escolhidos aleatoriamente, cada grupo ficou responsável por produzir materiais referentes aos sub-temas escolhidos.

Os estagiários tiveram a responsabilidade de orientar as devidas turmas durante três semanas, totalizando nove aulas por turma, para a apresentação do projeto solicitado. Os subtemas escolhidos pela turma envolviam estudos relacionados à melhores hábitos alimentares, foram cinco grupos compostos por seis alunos cada, eles trouxeram temas como: a importância da hidroginástica na melhor idade, o treinamento funcional, frutas e verduras na alimentação e a importância do suco natural apresentando experimentos.

As equipes ficaram responsáveis por apresentar à população a importância de cada tema escolhido, para que dessa forma levassem algum conteúdo à comunidade que os assistiriam. Foram realizados experimentos químicos que contabilizam o quantitativo de vitamina "c" em sucos naturais e industrializados, fazendo uma analogia e sensibilizando a população a reduzir o consumo de produtos industrializados.

Os grupos que abordaram os temas: treinamento funcional e hidroginástica, exemplificaram as atividades realizadas pelos profissionais da área e apresentaram os instrumentos utilizados levando-os para apresentar a comunidade. Os demais grupos apresentaram como temas transversais as enfermidades adquiridas pelo déficit de vitaminas no corpo provocada pela má alimentação. As equipes produziram materiais, slides, maquetes, cartazes e experimentos para exemplificar o tema escolhido, apresentaram para a escola e comunidade na data estabelecida pela equipe gestora da instituição de ensino.

\section{CONCLUSÃO}

A escola se mostrou muito receptiva e aberta ao diálogo, além de aceitar e ponderar o trabalho dos estagiários no exercício de sua função. O resultado final pode ser observado na presença maciça dos alunos nas aulas - desconsiderando as pequenas adversidades - ficando bastante visível a assiduidade dos alunos nas aulas aplicadas.

Essa atividade foi relevante no processo da formação docente dos estagiários. Deve-se considerar o estágio supervisionado como espaço de amadurecimento intelectual que permita, ao docente em formação, desenvolver as habilidades necessárias à prática docente, à produção de conhecimento pedagógico, à práxis e, ainda, à reflexão sobre a atividade docente. Então, como futuros profissionais de educação, os estagiários terão um maior embasamento para sua atuação em sala de aula.

Durante a experiência vivenciada ficou claro que diversas metodologias podem ser utilizadas no processo de ensino-aprendizagem, e o uso delas durante as aulas traz muito 
dinamismo e participação de todos, fato que auxilia na assimilação de conteúdos e aumenta interação de todos tornando o ambiente mais agradável.

Sobre o uso das atividades práticas, foi notório o fato de os estudantes adquirirem muito mais conhecimento através de situações concretas associadas à teoria. Os professores, ao deixarem de realizar atividades práticas podem estar incorporando formas de ação presentes historicamente no ensino, pautado por uma abordagem tradicional, sem maiores reflexões sobre a importância da prática na aprendizagem de ciências. (ANDRADE e MASSABNI, 2011, p. 836).

É importante salientar que a motivação do profissional de educação reflete intensamente no processo de ensino-aprendizagem, e foi o um dos pontos percebidos na escola onde o estágio foi realizado, trazendo conseqüências aos discentes intensificando a situação que já é complicada, pois também há a ausência dos pais na vida acadêmica e grande parte dos alunos que freqüentam a escola analisada moram em comunidades carentes e convivem com familiares envolvidos em tráfico de drogas, roubos, entre outros aspectos prejudiciais. Esses fatos contribuem na maioria das vezes com um processo de ensino insuficiente e baixo rendimento escolar por parte dos alunos. Outra dificuldade apontada é em relação à falta de recursos e materiais escolares para suprir as necessidades, que venham a contribuir com o desempenho dos trabalhos e facilitar a prática pedagógica dos docentes.

Dessa forma fica clara a influência e importância do profissional de educação assim como o apoio de toda a equipe gestora para um bom desempenho e crescimento escolar. Diante de todas as dificuldades, o fato de querer fazer diferente e acreditar na melhora da educação, são decisivos para a mudança desse quadro. Por fim podemos considerar o estágio como atividade detentora de uma importante função social, sendo ela a de integrar o acadêmico no mercado de trabalho, como profissional e como cidadão consciente e crítico (PERELLÓ, 1998).

\section{REFERÊNCIAS}

ANDRADE, M. L. F.; MASSABNI, V. G. O desenvolvimento de atividades práticas na escola: um desafio para os professores de ciências. Ciência \& Educação, v. 17, n. 4, p. 835-854, 2011.

MALDANER, O. A. A pesquisa como perspectiva de formação continuada de professores de Química. Revista Química Nova, v. 22, p. 289-292, 1999.

PEREIRA, B. B. Experimentação no ensino de ciências e o papel do professor na construção do conhecimento. Cadernos da FUCAMP, v. 9, n. 11, 2010.

PERELLÓ, J. S. Pedagogia do estágio: Experiências de formação profissional. Belo Horizonte: Imprensa Oficial, 1998.

PIMENTA, S. G.; LIMA, M. S. L. Estágio e docência. São Paulo: Cortez, 2004. (Coleção docência em formação. Séries saberes pedagógicos). 